\title{
THE NURSING SHORTAGE: A WORLDWIDE PROBLEM
}

Booth RZ. The nursing shortage: a worldwide problem. Rev latino-am Enfermagem 2002 maio-junho; 10(3):392-400.

A worldwide shortage of nurses has been acknowledged by the multidisciplinary Global Advisory Group of the World Health Organization. The shortage is caused by an increased demand for nurses, while fewer people are choosing nursing as a profession and the current nurses worldwide are aging. The shortage applies to nurses in practice as well as the nurse faculty who teach students. The inter-country recruitment and migration of nurses from developing countries to developed countries exacerbates the problem. Although public opinion polls identifies the nurse as the person who makes the health care system work for them, the conditions of the work environment in which the nurse functions is unsatisfactory and must change. Numerous studies have shown the positive effects on the nurse of a healthy work environment and the positive relationships between nursing care and patient outcomes. It is important that government officials, insurance companies, and administrators and leaders of health care systems acknowledge and operationalize the value of nurses to the health care system in order to establish and maintain the integrity and viability of that system.

DESCRIPTORS: nursing, shortage

\section{EL DÉFICIT DE LA ENFERMERÍA: UN PROBLEMA MUNDIAL}

El Grupo Consultivo Global, un grupo multidisciplinario de la Organización Mundial de la Salud, admite que hay un déficit de enfermeros a nivel mundial. Este déficit es el resultado de una mayor demanda por enfermeros, ya que un número pequeño de personas optan por la profesión y los enfermeros actualmente activos en todo el mundo están envejeciendo. El déficit es encontrado tanto entre los enfermeros clínicos como entre los docentes de enfermería. El reclutamiento entre países y la migración de enfermeros de países en desarrollo para países desarrollados hacen el problema aún más complejo. Aunque las investigaciones de la opinión pública identifiquen el enfermero como la persona que hace con que el sistema de salud funcione, las condiciones del ambiente de trabajo en el cual en enfermero actúa son insatisfactorias y necesitan cambiar. Varios estudios demuestran los efectos positivos de un ambiente de trabajo saludable sobre el enfermero, así como de las relaciones positivas entre el cuidado de enfermería y los resultados presentados por los pacientes. Es importante que gobernantes, empresas de planes de salud, administradores y líderes del sistema de cuidado a la salud reconozcan y operacionalizen la importancia del enfermero para el sistema de salud con el fin de establecer y mantener su integridad y viabilidad.

DESCRIPTORES: enfermería, déficit

\footnotetext{
${ }^{1}$ RN, PhD, Dean and Professor, University of Alabama School of Nursing, electronic address: rzbooth@uab.edu
} 


\section{O déficit dA ENFERMAGeM: UM PROBlema mUNDIAL}

O Grupo Consultivo Global, um grupo multidisciplinar da Organização Mundial de Saúde, tem admitido a existência de um déficit de enfermeiros em nível mundial. Tal déficit é o resultado de uma maior demanda por enfermeiros, já que um número pequeno de pessoas optam pela profissão e os enfermeiros atualmente ativos em todo o mundo já estão envelhecendo. O déficit é encontrado tanto entre os enfermeiros clínicos como entre os docentes de enfermagem. O recrutamento entre-países e a migração de enfermeiros de países em desenvolvimento para países desenvolvidos faz com que o problema se torne mais complexo. Embora pesquisas de opinião pública identifiquem o enfermeiro como a pessoa que faz com que o sistema de saúde funcione, as condições do ambiente de trabalho no qual o enfermeiro atua são insatisfatórias e precisam mudar. Vários estudos demonstram os efeitos positivos sobre o enfermeiro de um ambiente de trabalho saudável, assim como as relações positivas entre o cuidado de enfermagem e os resultados apresentados pelos pacientes. É importante que oficiais do governo, empresas de planos de saúde, administradores e líderes dos sistemas de cuidado à saúde reconheçam e operacionalizem a importância do enfermeiro para o sistema de saúde a fim de estabelecer e manter a sua integridade e viabilidade.

DESCRITORES: enfermagem, déficit

\section{INTRODUCTION}

A UN wire provided major news networks with a grim message concerning a serious nurse shortage around the globe. The demand for more and more nurses far exceeds the supply, with no expectation that the problem will be resolved soon. The multidisciplinary Global Advisory Group (GAG) for Nursing and Midwifery of the World Health Organization deliberated during its Sixth meeting relative to the effects of this shortage, including the effects of nurses migrating from country to country. The release reads as follows:

"Nurses and midwives around the globe are leaving the health system, driven away by underpay, hazardous working conditions, lack of career development, as well as professional status and autonomy. In addition, there is a sharp decline in new recruits to the profession for similar reasons. If the world's public health community does not correct this trend, the experts agreed, the ability of many health systems to function will be seriously jeopardized"(1).
Although thousands of miles and many differences separate countries and cultures, the message describes a worldwide problem. The simple truth is that nurses are not there for the people who need them most. Regardless of the country, the public's perception of their nurses resound with great similarities. That is, nurses hold the system together and serve as the advocate, health provider, educator, and administrator for making the system work well for them; nurses possess the highest level of integrity and honesty of any other health care workers and administrators; nurses are the ones who care about patients and their families; and "nurses are the backbone of the health care systems". The latter statement was attributed to Director General Gro Harlem Brundtland of $\mathrm{WHO}^{(2)}$.

Statistics included in the news release illustrated the reality of the dire need for nurses around the globe. For example, Zambia had only 500 of the 1,500 nurses needed for one of its hospitals. Chile had only 44.4 percent of its 18,000 nurses actively working in nursing, yet nurses were reported to "run" 94 percent of the 
well-baby clinics in that country. Poland had a 70 percent decline in nurses graduating from its nursing programs during the previous decade. Likewise, in six short years between 1995 and 2001, there was a 26 percent decrease in nursing school graduates taking the licensure examination to become a Registered Nurse (RN) in the United States.

Not only is there a scarcity of human resources, there is an equal scarcity of material resources. The attendees at the American Nurse's Association Convention that nurses use plastic shopping bags when delivering newborns in some parts of Africa to protect themselves and the newborn from $\mathrm{HIV}^{(2)}$. Nurses in Central and Eastern Europe may not have the basic supplies or drugs to deliver the care needed by patients. But these nurses persevere even in highly unsatisfactory working conditions because they care.

Doing the best they can with little or no resources does not translate into an attractive career option for individuals to choose nursing. Why, one may ask, are nurses deemed so important by the recipients of care and health care leaders and yet they - - the nurses - - are underpaid, work in inadequate environmental conditions, are not involved in decision making, and do not receive support for career development? Two reasons loom strong - - a large majority of nurses are female and females are not valued highly compared to males, although progress has been made in some countries, and society has placed an aura around illness and all its equipment, therapies, and treatments. A "do not worry mentality" pervades society because "we have a pill for you". Thus, the system does not provide incentives to remain well, even though the costs, pain, and suffering would be decreased significantly with a reward system for staying well. Will the leaders of our countries allow these conditions to prevail and, therefore, jeopardize the ability of their health systems and their people to function, while the demand (need) for nurses continues to grow but the nurses are not there? Specifically, who will answer the call light when a patient calls for help and the nurses are not there?

The world currently has more nurses than ever, yet the shortage is the most serious experienced in history. With approximately 11 million nurses worldwide, the insatiable demand continues to grow for more. A common constellation of reasons for the shortage exists from country to country, with the central reason being an increased demand (need). Some of these reasons are, in general, a) a growing number of hospitalized patients who are more acutely ill, b) the development of new procedures and therapies, to include the use of technology, c) an increase in use of nurses in community based, primary care services, d) diseases that are spreading in epidemic proportions, and e) an aging population who will comprise 20 percent of the world's population by $2025^{(3)}$. For example, in 2000 the elderly comprised a range of 3.1 percent of the total population in Qatar to 24.1 percent in Italy and Marino $^{(3)}$.

Historically, nursing has been a profession comprised of women in most countries; however, opportunities are becoming more and more available and attractive to females in non-traditional professions or occupations, such as engineering, medicine, law, accounting, and business. Due to this change, the profession is losing its prime source of new recruits and incentives are not yet sufficient to attract adequate numbers of males to replace the loss. 
Another cause for the shortage is the aging of the nurse workforce. In the U.S., the average age of all RNs is 45 years $^{(4)}$, while the average age of faculty in bachelor's and higher degree nursing programs is 50.5 years $^{(5)}$. In $1980,52.9$ percent of all RNs in the U.S. were less than 40 years old, but by the year 2000 that percent had declined to $31.7^{(4)}$. According to a report issued by the U.S. Accounting Office, 40 percent of all RNs in the U.S. will be 50 years or older by 2010 (www.gao.gov). Likewise, the average age of Canadian nurses is reported to be 47 years, with only 5 percent of their nurses under 30 years of age ${ }^{(6)}$. In the U.S., large numbers of faculty are retiring and fewer nurses have been choosing the educator role for the past decade; thus, the shortage of faculty is going to be a long-term problem. Countries are beginning to actively recruit for faculty from other countries, which indicates the beginning of an inter-country shortage of nurse faculty.

The Canadian Nursing Association projects a possible shortage in that country of $59,000-113,000$ nurses by $2011^{(6)}$. The U.S. Department of Labor projects a need for 450,000 additional registered nurses by 2008 in order to meet the demand. The aging of nurses, coupled with the difficulty in attracting new recruits into the profession while the demand for more nurses continues to increase, results in a bleak situation for the health care system.

Representatives from many countries have acknowledged that the work environment of the nurse is causing nurses to withdraw from the profession and discourages persons from choosing the profession. A study ${ }^{(7)}$ reveals findings that verifies the conditions explicated in the news release issued by the WHO. In this study, the subjects consisted of 43,329 nurses who worked in 700 hospitals for acute care of adults in the five countries of Germany, Scotland, England, Canada, and the United States. Among four of the five hospitals, the findings showed nurse shortages, high job dissatisfaction, less advancement opportunities, and quality of care concerns. Interestingly, less than 50 percent of the nurses believed they were involved in decision-making or that management listened or responded to their concerns, as well as lacked recognition for the important roles that nurses played in providing care. Unlike the other four countries, nurses in Germany had higher job satisfaction, lower burnout from job-related stress, more input into work scheduling, and greater recognition for the valuable role nurses fulfill in patient care.

Having data to inform us about the shortage and reasons for dissatisfaction, what are the solutions? During a previous nursing shortage in the U.S., studies were conducted to identify the characteristics of those hospitals that did and did not have problems with recruiting and retaining nurses. Hospitals that were successful in recruiting and retaining, even during a nurse shortage, looked different in terms of leadership characteristics of the administrator, professional practice of the nurse, a supportive environment, and a relationship between nursing and patient outcomes. These hospitals were designated as magnet hospitals $^{(8-11)}$ and a process exists to this day for hospital nursing departments to apply for magnet status if it can be demonstrated that these characteristics exist in the department.

The leadership attributes of the nurse administrator were described as visionary, proactive, and supportive of staff. The administrator demonstrated support via good and consistent communications, supported a 
program for career development, was visible and responsive to staff, represented staff in important venues in the organization, and valued the staffs' knowledge and abilities. Nurses felt empowered and were supported for their autonomy and control of professional practice and for maintaining professional relationships with colleagues. Professional practice was attained by using a primary nursing model whereby the designated primary nurse had 24 hours per day, seven days per week responsibility for the plan and provision of care for assigned patients. Associate nurses assisted the primary nurse in providing this continuous and comprehensive care to the patient from admission to discharge. Further, nurses were involved in both clinical and organizational decision-making, maintained a mutual respect with physicians, and maintained a standard of high quality patient care. The results found in these magnet hospitals showed high job satisfaction of nurses, greater autonomy and control of professional practice, lower mortality rates of patients, and high patient satisfaction.

\section{EFFECT OF MIGRATION ON THE SHORTAGE}

The retention of nurses is just as important as the recruitment of nurses, i.e., retention in one's home country and retention in the same employment agency. However, the worldwide shortage of nurses has accelerated the recruitment of nurses from other countries and has caused serious retention and migration problems. Developed countries are causing shortages in developing countries by recruiting their nurses. Dr. Naeema Al-Gasseer, Senior Scientist for the WHO maintains that "The poor are always the first to suffer during times of health care crisis"(1). The serious nurse shortage in Jamaica serves as an example of Dr. Naeema's concern in that Jamaica has recruited nurses from Ghana to assist in alleviating its shortage, yet Jamaican nurses are migrating to the United Kingdom. In a January edition of the U.S. Wall Street Journal, it was reported that 500 nurses, double the number of nurses in the country who graduated, left Ghana last year to work in other countries ${ }^{(12)}$. Also, Coates acknowledges in a May 14, 2001 edition of the London Guardian that there has been a "71 percent increase in overseas-trained nurses applying to register in the United Kingdom, including almost 13,750 from the Philippines; 2,459 from India; 2,065 from Nigeria; and 2,056 from South Africa". Guidelines for inter-country recruitment of nurses have been developed by the British government which will place limits on recruitment in certain countries. These guidelines address some of the concerns raised by the GAG and the International Council of Nurses (ICN) about inter-country recruitment of nurses.

Due to the effect that migration has on the developing and least developed countries, the GAG for Nursing and Midwifery requests that the WHO Director General "provide support to member states in setting up mechanisms for inquiry into the global shortage of nursing and midwifery personnel, including the impact of migration, and in developing human resources plans and programs, including ethical recruitment" ${ }^{\text {(13). }}$. The ICN agrees that countries do not provide the working conditions and incentives that retain nurses in their respective countries. Neither does the ICN support intercounty recruitment as shown in its position statement on Nurse Retention, Transfer and Migration: 
"ICN and its member associations firmly believe that quality health care is directly dependent on an adequate supply of qualified nursing personnel.

ICN recognises the right of individual nurses to migrate, while acknowledging the potential adverse effect that international migration may have on health care quality.

ICN condemns the practice of recruiting nurses to countries where authorities have failed to address human resource planning and problems which cause nurses to leave the

profession and discourages them from returning to nursing"(14).

\section{PUBLIC'S OPINION OF NURSES}

Although nurses may be dissatisfied with their work environment and believe they have to leave that environment to seek a better one, they continue to provide patients with quality care that instills confidence and respect by the public. Was reported ${ }^{(2)}$ that 96 percent of patients in the UK were satisfied with the work that nurses do. Likewise, the public in Australia trusted nurses more than any other professional. The American public made known their opinions when asked about the most ethical and honest among all occupations ${ }^{(15)}$. Nurses topped the list followed by pharmacists, veterinarians, medical doctors, $\mathrm{K}-12$ teachers, judges, policemen, dentists, and college teachers.

In the developing and least developed countries, the nurse may be the only health professional available to the community. The nurse may teach the basic principles of hygiene, nutrition, and food production and preservation to the family, as well as the preventive aspects of health care and the curing aspects of illness. Nurses may be the only health professional available to the children in the schools and the entire family when they need assistance. Nurses become the symbol for giving those families and individuals the desire to improve their total lifestyle, as well as their health.

\section{RELATIONSHIPS BETWEEN NURSING AND PATIENT OUTCOMES}

Opinion surveys provide valuable information about the health system and nurses; however, other studies that use a rigorous research process are needed to show the link between the care provided and outcomes. One such study is a multi-phase project started by the American Nurse's Association (ANA) in 1994 that resulted in the identification of 10 nurse-sensitive quality indicators in acute care settings. The 10 indicators are: nosocomial infection rate; patient injury rate (falls); maintenance of skin integrity (pressure ulcers); patient satisfaction with nursing care; patient satisfaction with overall care; patient satisfaction with pain management; patient satisfaction with educational information; nurse staff satisfaction; mix of RNs, LPNs, and unlicensed staff; and total nursing care hours provided per patient day ${ }^{(16)}$. The findings from several of these studies reveal a statistically significant inverse relationship between either the percent of RN hours or nursing hours per patient day (NHPPD) and patient outcomes. It was found ${ }^{(17)}$ a statistically significant inverse relationship between percent of RN hours and the outcomes of pressure ulcers, urinary tract infections, and post-operative infections. A less robust inverse significance was found between the percent of 
RN hours and length of stay, although there was a strong correlation between length of stay and NHPPD (includes all types of nursing staff). When examining the relationship between NHPPD and RN hours with six patient outcomes, it was found ${ }^{(18)}$ an inverse relationship between $\mathrm{RN}$ hours and medication errors, decubiti, and patient complaints, plus "a relationship" between NHPPD and rates of decubiti, patient complaints, and mortality.

It was found ${ }^{(19)}$ a statistically significant inverse relationship between NHPPD and length of stay in 10 of 11 patient units they studied. The 10 units were cardiac stepdown, ICU, medical-surgical, neurology, oncology, orthopedics, obstetrics, pediatrics, psychiatry, and rehabilitation. Only the neonatal unit, the eleventh unit, had a lower length of stay with lower NHPPD.

In addition to the nurse-sensitive quality indicators for acute care, the ANA has also identified 10 nurse-sensitive quality indicators for community, non-acute care settings. Studies are underway in examining the relationships between nursing and patient/client outcomes in those settings. The 10 nurse-sensitive quality indicators for community, non-acute settings are:

- pain management

- consistency of communication

- staff mix

- client satisfaction

- prevention of tobacco use

- cardiovascular (disease) prevention

- caregiver activity

- identification of primary caregiver

- psychosocial interaction

- activities of daily living/instrumental activities of daily living ${ }^{(16)}$.

Although not part of the ANA nurse- sensitive quality indicators' studies, other studies have been conducted on the quality and outcomes of advanced nursing practice, that is, those nurses with graduate degrees. The findings have shown that nurse practitioners (one advanced nurse practice group) are able to provide 80-90 percent of the primary care traditionally provided by physicians in the U.S. ${ }^{(20)}$, yet the direct costs for educating a nurse is only one-fifth the amount to educate a physician $^{(21)}$. Also, nurse practitioners (NPs) use fewer drugs and more nondrug therapeutic measures $^{(22)}$, and spend more time per patient visit but costs are less per visit ${ }^{(23)}$. Furthermore, patient satisfaction is high; care outcomes are equivalent or better than for physicians; communication and interpersonal relationships are of higher quality; and patient compliance is greater $^{(23-24)}$. It was ${ }^{(25)}$ studied two matched groups of 35 infants each and compared the care provided by neonatal nurse practitioners (NPs) and medical house staff (physicians). The findings showed that infants cared for by NPs remained an average of 14 days less in the neonatal ICU, were on the ventilator five fewer days and oxygen therapy 10 few days, costs U.S. \$18,240 less per infant, and had greater continuity and consistency of care.

Similar results were found in a study ${ }^{(26)}$, where home care provided to mothers and infants by advanced practice nurses resulted in lower infant mortality, better maternal and infant care, and less costs. Also, there were fewer preterm births, fewer prenatal hospitalizations, and a savings of U.S. $\$ 2,880,000$.

The findings from the studies of NPs validate $^{(27)}$ proposed strategies that could reduce need and demand for health services, thereby reducing costs of health care. Nurses 
are most capable of assuming the lead role in implementing these strategies that are listed below:

- preventing disease by reducing risky behaviors and promoting healthy life styles;

- teaching consumers to manage their own care and the efficient use of services, and

- communicating to patients their options for care during a terminal illness other than the typical intensive services in order to reduce costs and most likely provide a more comfortable environment for care to both the patient and the family.

\section{FINAL CONSIDERATIONS}

The global nursing shortage in both practice and education is multifaceted. Fewer individuals are choosing to enter the profession; women (the primary source for recruiting nurses) are now attracted to other professions; the market demand for more nurses has increased dramatically; the nursing profession is aging; and nurses are retiring in large numbers.

On the other hand, the demand for more nurses is increasing for several reasons, including higher percentages of the 60 years and older population. These older individuals have more chronic diseases and become acutely ill; thus, frequently need hospitalization. Due to the low value placed on health and health promotion, more acute and chronic illnesses that require more and more pharmaceuticals, equipment, supplies, and health care workers - health care costs continue to rise and the demand for nurses continues to grow. What are the solutions?

- Governmental officials and insurance companies must establish policies that will redirect resources to health promotion and disease prevention and reward providers and consumers for remaining healthy. The program must include an education component to reeducate, re-socialize, and reward the population to maintain healthy lifestyles and health.

- Accept the research findings that show the value, both in terms of patient outcomes and costs, of nurses and reward them in both financial terms and satisfactory work conditions.

- Devote financial resources and programs to recruit in elementary, middle school, and high schools, and target both males and females. - Involve nurses in the design and the operation of the organization, to include the practice site whether the role is clinical, education, or research/scholarship.

- Provide a career development program for knowledge updates and career progression.

Research has shown that the nurse administrator, the practice environment, the valuing of the nurse, the granting of autonomy in decision making relative to the practice and the organization, and the valuing of patient care have a statistically significant effect on the nurse's satisfaction and the quality of care.

While studies have been conducted in some countries to link nursing care to patient outcomes, there is a need for more multinational studies to be conducted. Evidence gained from these studies could be used to improve health care systems, as well as to improve the image, satisfaction, career development, and work environment of the nurses. The barriers to the achievement of positive outcomes for the patient and the nurse must be eliminated for the survival of health systems worldwide. In a U.S. Congresswoman's own words "Solving the shortage is not just the right thing to do for our nurses, it's the right thing to do for health care..."(28) and for countries around the globe. 


\section{REFERENCES}

1. News release. Nursing and midwifery services facing crisis, experts say. Geneva, Switzerland: World Health Organization; 2000.

2. Stallknecht K. American Nurse's Convention Speech. Available from: URL: http://www.icn.ch/ anaspeech_00.htm.

3. World Health Report. Mental health: New understanding, new hope. Geneva, Switzerland: World Health Organization, 2001.

4. HRSA News Release. HRSA national survey cites slowdown in number of Registered Nurses entering profession. Avaliable from: URL: http://www.hrsa.gov/ neusroom/releases/2001\%20Releases/nursesurvey.htm. 5. Berlin L, Bednash G, Stennett J. 2000-2001 Salaries of Instructional and Administrative Nursing Faculty in Baccalaureate and Graduate Programs in Nursing. Washington (DC): American Association of Colleges of Nursing; 2001.

6. Registered Nurses' Association of B.C. The nurse shortage. Available from: URL: http://www.rnabc.bc.ca/ newnews/shortage.htm.

7. Aiken L, Clarke S, Sloane D, Sochalski J, Busse R, Clarke $\mathrm{H}$, et al. Nurse's report on hospital care in five countries. Health Affairs 2001; 20(3):43-53.

8. McClure M, Poulin M, Sovie M. Magnet Hospitals: Attraction and Retention of Professional Nurses. Kansas City, Missouri: American Academy of Nurses; 1983.

9. Aiken L, Smith H, Lake E. Lower Medicare mortality among a set of hospitals known for good nursing care. Medical Care 1994; 32(5):771-87.

10. Aiken L, Sloane D, Lake E. Satisfaction with inpatient AIDS care: a national comparison of dedicated and scattered-bed units. Medical Care 1996; 35(9)948-62.

11. Scott J, Sochalski J, Aiken L. Review of magnet hospital research. J Nurs Admin 1999; 29(1):9-19.

12. Coates K. [cited 2001 Jun 11]. Trickle-down effect. Available from: URL: http://www.nurseweek.com/ news/ features/01-06/global.html.

13. Strengthening Nursing and Midwifery. Resolution of the Executive Board, Global Advisory Group, $107^{\text {th }}$ Session. Geneva, Switzerland: World Health Organization; 2001.

14. Position Statement. [cited 1999]. Nurse retention, transfer and migration. International Council of Nurses. Available from: URL: http://www.icn.ch/psretention.htm. 15. Honesty and Ethics Poll. Princeton, (NJ): Gallup Organization; 1999.

16. Trossman S. Nurses nationwide want to show link between RN care and quality patient care. The American Nurse. Washington (DC): American Nurse's Association; 2000.
17. Lichtig L, Knauf R, Milholland D. Some impacts of nursing on acute care hospital outcomes. Journal of Nursing Administration 1999; 29(2):25-33.

18. Blegen M, Goode C, Reed L. Nurse staffing and patient outcomes. Nursing Research 1998; 47:43-50.

19. Shamian J, Hagen B, Hu T, Fogarty T. The relationship between length of stay and required nursing care hours. J Nurs Admin 1994; 24(7/8):52-8.

20. Office of Technology Assessment, United States Congress. Nurse practitioners, physician assistants, and certified nurse midwives: A policy analysis. Washington (DC): U.S. Government Printing Office, Health Technology Case Study 37, OTA-HCS-37; 1986.

21. Safriet $B$. Health care dollars and regulatory sense: The role of advanced practice nursing. Yale Journal on Regulation 1992; 9(2):417-87.

22. Mahoney D. Appropriateness of geriatric prescribing decisions made by nurse practitioners and physicians. Image: Journal of Nursing Scholarship 1994; 26(1):41-6. 23. Brown S, Grimes D. Nurse practitioners and nurse midwives. A meta-analysis of studies on nurses in primary care roles. Washington (DC): American Nurses' Association; 1993.

24. Feldman M, Ventura M, Crosby F. Studies of nurse practitioners effectiveness. Nursing Research 1987; 36:303-8.

25. Bissinger R, Allred C, Arford P, Bellig L. A cost-effective analysis of neonatal nurse practitioners. Nursing Economics 1997; 15(2):92-9.

26. Brooten D, Youngblut J, Brown L, Finkler S, Neff D, Madigan E. A randomized trial of nurse specialist home care for women with high-risk pregnancies: Outcomes and costs. American Journal of Managed Care 2001; 7(8):793-803.

27. Fries J, Koop C, Beadle C, Cooper P, England M, Greaves $\mathrm{R}$, et al. Reducing health care costs by reducing the need and demand for medical services. New England Journal of Medicine 1993; 329(5):321-5.

28. House panel hears concerns about nursing shortage; 2001 October. 